Article Type: Commentary

NOTES

Ref 5: [add details at production]

COMMENTARY

JP June 2016

Ms. No. 15/2266-Commentary

\title{
Female pattern hair loss, biological ageing and the Leiden Longevity study
}

DOI: $\mathrm{xx}$ [add details at production]

Linked Article: Noordam et al. Br J Dermatol 2016; xxx:xxx-Xxx. [add details at production

R. Sinclair

Department of Dermatology, University of Melbourne, 2 Wellington Parade, East Melbourne, Victoria 3002, Australia

\section{Correspondence}

E-mail: rodney.sinclair@sinclairdermatology.com.au

\section{Funding sources}

No external funding.

\section{Conflicts of interest}

None to declare.

People age at different rates and individuals with the same chronological age vary widely in terms of health and function. ${ }^{1}$ Biological age describes the difference between the population cohort average life expectancy and the perceived life expectancy of an individual of the same age. Essentially it is an indication of how well your body is functioning relative to your calendar age.

This is the author manuscript accepted for publication and has undergone full peer review but has not been through the copyediting, typesetting, pagination and proofreading process, which may lead to differences between this version and the Version of Record. Please cite this article as doi: 10.1111/bjd.14829 
Biomarkers commonly used to determine biological age include diet, stress levels, alcohol consumption, education levels, sleep patterns, sexual habits, blood pressure, resting heart rate, strength and mobility. ${ }^{2}$

Should patterned hair loss also be considered to be a phenotypic marker of biological ageing?

Men and women both lose hair progressively with advancing age $\mathrm{e}^{3}$ and men and women with premature hair loss appear prematurely aged. Men and women with premature hair loss also have an increased risk of death overall and in particular from diabetes mellitus and heart disease. This risk persists after adjusting for the known association between patterned hair loss and metabolic syndrome. ${ }^{4}$

Noordam et al. ${ }^{5}$ in this month's edition of the British Journal of Dermatology used patient data from the Leiden Longevity study to demonstrate that women with known cardiovascular risk factors such as low high-density lipoprotein cholesterol and hypertension and biomarkers of ageing such as insulin-like growth factor-1 and vitamin D levels have an increased risk of female-pattern hair loss (FPHL). Noordam et al. ${ }^{5}$ also found that more advanced FPHL is associated with additional biomarkers of ageing and longevity. This supports the contention that FPHL is a biological marker of senescence and predictor of reduced longevity.

Male and female pattern hair loss are both genetically based, suggesting that they contribute to evolutionary fitness. Male-pattern hair loss (MPHL) and in particular premature MPHL has a negative impact on reproduction. ${ }^{6}$ While MPHL does not affect virility, premature MPHL makes some men less sexually attractive. Overall, men with premature hair loss average fewer lifetime sexual partners. ${ }^{7}$

FPHL normally occurs at or after menopause and signals waning fertility to a prospective mate. Women with premature FPHL appear prematurely aged and may be less sexually attractive. In addition to the psychological problems associated with premature FPHL, ${ }^{8}$ affected women appear to have an increased risk of metabolic syndrome, polycystic ovarian syndrome, hypertension, diabetes and hypercholesterolemia. ${ }^{4,9}$

Additional epigenetic factors such as methylation of the androgen receptor gene are involved both in the pathogenesis and patterning of MPHL ${ }^{10}$ and the pathogenesis of ageing. Epigenetic methylation is considered to be a specific biomarker of organ-specific biological ageing. ${ }^{11}$

Baldness severity is an important guide when assessing the chronological age of a stranger. Moreover, patterned hair loss is also likely to be a phenotypic marker of senescence and premature patterned hair loss is an indicator of reduced longevity and reduced evolutionary 
fitness. Perhaps that is why some people perceive hair loss negatively and those who become our patients feel sufficiently distressed by their hair loss to see dermatologists and hair transplant surgeons for treatment.

\section{References}

1 Mitnitski AB, Graham JE, Mogilner AJ, Rockwood K. Frailty, fitness and late-life mortality in relation to chronological and biological age. BMC Geriatrics 2002; 27:1. 2 Borkan GA, Norris AH. Assessment of biological age using a profile of physical parameters. J Gerontol 1980; 35:177-84.

3 Gan DCC, Sinclair RD. Prevalence of male and female pattern hair loss in Maryborough. J Invest Dermatol Symp Proc 2005; 10:184-9.

4 Su LH, Chen LS, Lin SC, Chen HH. Association of androgenetic alopecia with mortality from diabetes mellitus and heart disease. JAMA Dermatology 2013; 149:601-6.

5 Noordam R, Gunn DA, van Drielen K et al. Low circulating insulin-like growth factor-1 and high-density lipoprotein cholesterol are associated with hair loss in middle-aged women. Br J Dermatol 2016. doi: 10.1111/bjd.14529. [add details at production]

6 Muscarella F, Cunningham MR. The evolutionary significance and social perception of male pattern baldness and facial hair. Ethology Sociobiol 1996; 17:99-117.

7 Sinclair RD, English DR, Giles GG. Are bald men more virile than their well-thatched contemporaries? MJA 2013; 199:811-12.

8 Cash TF, Price VH, Savin RC. Psychological effects of androgenetic alopecia on women: comparisons with balding men and with female control subjects. J Am Acad Dermatol 1993; 29:568-75.

9 Yi SM, Son SW, Lee KG et al. Gender-specific association of androgenetic alopecia with metabolic syndrome in a middle-aged Korean population. Br J Dermatol 2002; 167:306-13.

10 Cobb JE, Wong NC, Yip LW et al. Evidence of increased DNA methylation of the androgen receptor gene in occipital hair follicles from men with androgenetic alopecia. $\mathrm{Br}$ J Dermatol 2011; 165:210-13.

11 Horvath S. DNA methylation age of human tissues and cell types. Genome Biol 2012; 14:1-20. 


\section{University Library}

\section{- M M I N E R VA A gateway to Melbourne's research publications}

Minerva Access is the Institutional Repository of The University of Melbourne

Author/s:

Sinclair, $R$

Title:

Female pattern hair loss, biological ageing and the Leiden Longevity study

Date:

2016-10-01

Citation:

Sinclair, R. (2016). Female pattern hair loss, biological ageing and the Leiden Longevity study. BRITISH JOURNAL OF DERMATOLOGY, 175 (4), pp.671-672. https://doi.org/10.1111/ bjd. 14829 .

Persistent Link:

http://hdl.handle.net/11343/291753 